\title{
Diatoms as indicators of historical water quality: A comparison of samples taken in the Wemmershoek catchment (Western Province, South Africa) in 1960 and 2008
}

\author{
WR Harding ${ }^{1 *}$ and JC Taylor 2,3 \\ ${ }^{\prime}$ DH Environmental Consulting, Cape Town, South Africa \\ ${ }^{2}$ School of Biological Sciences, North-West University, Potchefstroom, South Africa \\ ${ }^{3}$ South African Institute for Aquatic Biodiversity, Grahamstown, South Africa
}

\begin{abstract}
Historical diatom records provide a means of retrospectively determining water quality and inferring ecological condition in rivers and streams. In this study we re-sampled sites originally sampled 48 years previously. We then determined the scores for the Biological Diatom Index (BDI) and the South African Diatom Index (SADI) for each dataset. The results revealed that the present day conditions in this relatively undisturbed locality were almost identical to those reflected by the samples collected half a century before. This illustrates the value of historical diatom data for the purposes of determining antecedent water quality.
\end{abstract}

Keywords: diatoms, water quality, South Africa, Biological Diatom Index, South African Diatom Index

\section{INTRODUCTION}

Diatoms serve as powerful bio-indicators for aquatic environments, determined either from historical or contemporary samples (e.g. Telford et al., 2002). The routine use of diatoms is well established in many countries (e.g. Kelly et al., 1998), but is an approach new to South Africa. Diatoms are now being used with increasing regularity in South Africa, as indicators of water quality (e.g. Harding et. al., 2005; Taylor et. al. 2007a), and applied within the scope of the River Health Programme (RHP, 2005). Diatom records contained in curated collections provide the basis for a robust interpretation of past conditions that, in the majority of cases, is not possible by other means (Harding et al., 2005; Taylor et al., 2005; Yallop et al., 2009; Kelly et al., 2012). South Africa benefits from a substantial diatom collection spanning the period from the late-1950s to the present (Taylor et al., 2011). The bulk of the early samples span the post-WWII period from the 1950s to the 1970s, i.e., prior to and through a period of substantial economic development in South Africa and the accompanying anthropogenic impact. As such, the South African National Diatom Collection (SANDC) provides an unequalled resource of historical 'reference condition' material spanning much of South Africa, as well as Namibia and other locations in southern Africa (Harding et al., 2004; Harding and Taylor, 2011).

The SANDC contains a vast amount of material besides the usual collection materials (slides, samples, etc.). The South African diatomologist Bela Cholnoky and his students, Archibald and Schoeman, determined and enumerated almost every slide examined and both the published and unpublished

To whom all correspondence should be addressed. 푤 +27 72 0267260; e-mail: info@dhec.co.za Received 29 August 2013; accepted in revised form 4 September 2014 analysis sheets may be found in the SANDC. Modern biomonitoring standards, to which present-day South African analysts adhere, dictate that at least 400 valves be enumerated from each sample (Taylor et al., 2005). The majority of the analysis sheets from as early as 1950 contain community composition counts of approximately 400 valves. This makes these sheets eminently suitable for calculating diatom index valves based on these historical analyses.

In 1957 the City of Cape Town (Western Cape Province, South Africa) commissioned the Wemmershoek Dam, located near the town of Paarl. Subsequent to the dam being flooded for the first time, the appearance in 1960 of some perceived water quality problems in the form of dense populations of chironomids, caused the local authority to commission a diatom-based assessment of the condition of the feeder rivers and streams (Cholnoky and Claus, 1961). This was probably the first application of diatoms for water quality monitoring in South Africa.

This paper examines the findings of a comparison of the diatom samples collected and analysed by Cholnoky from localities within the Wemmershoek Dam catchment area, with samples collected from the same sites and analysed by these authors 48 years later.

\section{STUDY AREA}

Wemmershoek Dam (33.833 S, 19.083 E) is located in a mountainous valley and fed by 4 seasonal rivers and several small streams. The catchment watercourses combine to form the Wemmershoek River (see Figs 1 and 2). The climate is Mediterranean with rainfall during the winter. Since the commissioning of the dam, land use in the catchment has been limited to silviculture (Pinus pinaster Aiton) on the northern shoreline and in the Olifants River valley to the east of the dam. Some derelict farm buildings and ruins from the former 


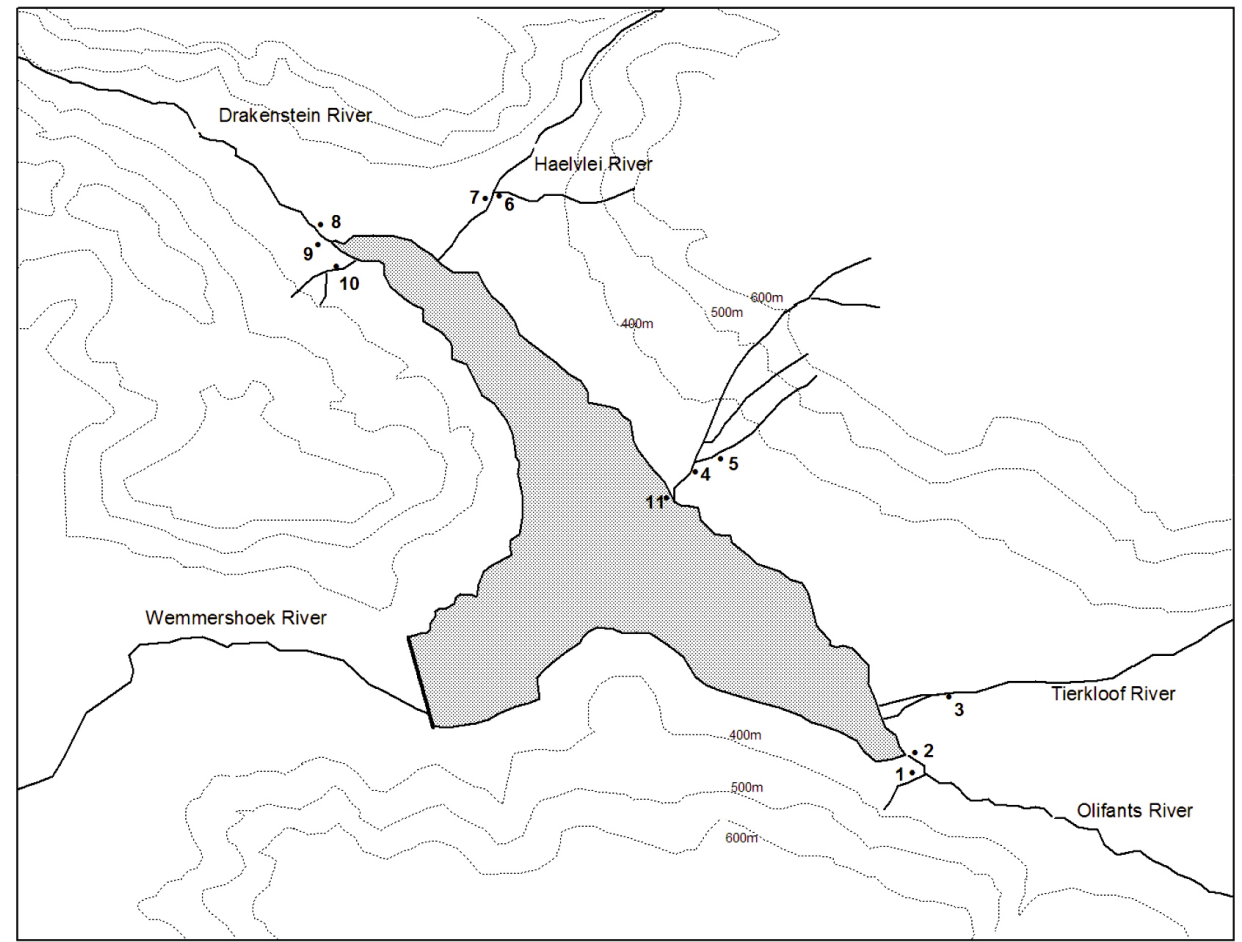

Figure 1

Map of Wemmershoek

Dam showing the watercourses relevant

to this study. Local

topography is shown as the 400-600 m contours.

North is above and the length of the dam wall (southwest) is $580 \mathrm{~m}$. The sample sites as used in the 1960 assessment are shown numbered from $1-11$.

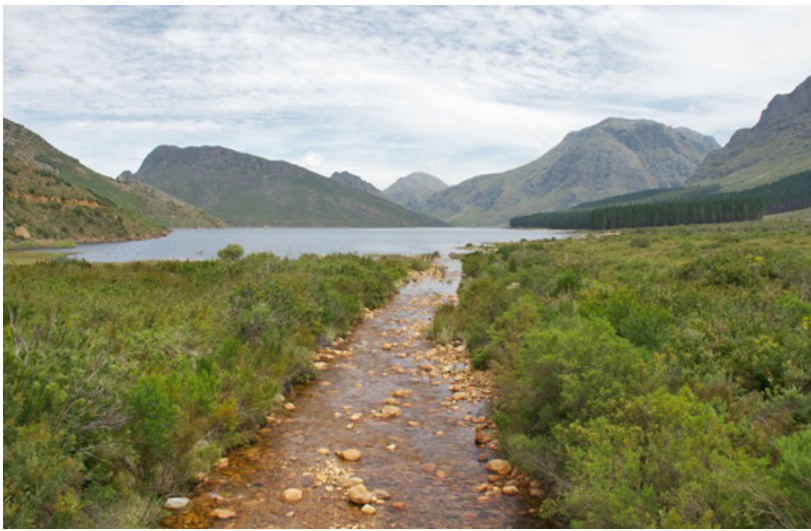

Figure 2

View northwest of the Olifants River entering Wemmershoek Dam. The inflow of the Drakenstein River lies directly opposite (see Fig. 1)

Winterhoek farm are scattered to the north and east of the dam. The natural water quality of this region is typified by acidic conditions, with humic-stained waters draining from fynbos-dominated mountain catchments (Allanson et al. 1990) In summary, the catchment has remained essentially unaltered since the dam was constructed.

\section{METHODS}

The original set of samples was collected from 11 sites on 25 October 1960 (Cholnoky and Claus, 1961). The samples for this comparative assessment were collected on 2 December 2008. Some of the smaller watercourses were dry and sample collections were only possible from 7 sites, as detailed in Table 1 and shown in Fig. 1.

The samples were collected, preserved, processed and analysed as described in Taylor et al. (2007b). At all sites the samples were brushed off cobbles as per the described methods. The

\begin{tabular}{|l|l|}
\hline \multicolumn{1}{|c|}{$\begin{array}{c}\text { TABLE } 1 \\
\text { Details of sample locations used in the } 1960 \text { and } 2008 \\
\text { Wemmershoek Dam diatom assessments }\end{array}$} \\
\hline $\begin{array}{l}\text { Site } \\
\text { Number* }\end{array}$ & Site description \\
\hline 1 & $\begin{array}{l}\text { Small tributary stream to Olifants River (dry in } \\
\text { December 2008) }\end{array}$ \\
\hline 2 & Olifants River mainstem \\
\hline 3 & Tierkloof River mainstem \\
\hline 4 & 'Farm Stream' \\
\hline 5 & $\begin{array}{l}\text { Small tributary of the Farm Stream (dry in } \\
\text { December 2008) }\end{array}$ \\
\hline 6 & $\begin{array}{l}\text { Small tributary of unnamed river (dry in } \\
\text { December 2008) }\end{array}$ \\
\hline 7 & Haelvlei River mainstem \\
\hline 8 & Drakenstein River mainstem \\
\hline 9 & Large spring emerging from the cliff-face \\
\hline 10 & $\begin{array}{l}\text { Small spring higher on the cliff-face (dry in } \\
\text { December 2008) }\end{array}$ \\
\hline 11 & $\begin{array}{l}\text { Littoral zone in the dam adjacent to the mouth of } \\
\text { the Farm Stream }\end{array}$ \\
\hline
\end{tabular}

*as per Cholnoky and Claus, 1961

original diatom analysis sheets were sourced from the South African National Diatom Collection and taxonomically updated to reflect contemporary nomenclature. Thereafter both sets of data were analysed using the OMNIDIA v. 5.3 software package (Lecointe et al., 1993) to generate values for the Biological Diatom Index (BDI) and for the recently developed South African Diatom Index (SADI), based on the French Specific Pollution sensitivity index or SPI (Harding and Taylor, 2011).

Collection of physico-chemical field data was limited to the in situ measurement of electrical conductivity (EC, milliSiemens per meter), using a Hach SensIon EC meter. 


\section{RESULTS AND DISCUSSION}

Seven samples were collected in 2008 from the sites as shown in Table 1. Measurements of electrical conductivity were typical of mountain stream water in the region and ranged from $1.2-3.7 \mathrm{mS} \cdot \mathrm{m}^{-1}$.

\section{Diatom assemblages}

The diatom assemblages and count data are presented for the original and contemporary samples in, respectively, Tables 2 and 3. Table 2 reflects the nomenclature used by Cholnoky and Claus, as well as the contemporary nomenclature.

Diatom communities from both surveys were dominated by those taxa that typically indicate acidic, oligotrophic waters with a low mineral content (as reflected by the low EC values). Both sets of analysis showed communities dominated by the acidophilic diatom genus Eunotia Ehrenberg. Interestingly, there seems to have been some grounds for the concerns of the Cape Town City council as Cholnoky's analysis shows that at Site 5 there is a slight (but not dramatic) increase in the taxa indicative of water quality impacts (e.g., the genus Nitzschia Hassall, especially Nitzschia palea (Kützing) W.Smith). Cholnoky, as an early pioneer of water quality monitoring using diatoms, used an early metric of impact that he dubbed his measure of 'heterotrophic diatoms'. This measure was a simple percentage calculation that included the taxa that he, in previous studies, had observed to be flourishing in nutrient/ organic material enriched conditions (e.g. Sellaphora (Navicula) seminulum (Grunow) D.G. Mann, Nitzschia palea and other Nitzschia taxa. This metric proved remarkably useful for classifying impact in streams (see discussion in Taylor et al., 2005) and matches well with modern metrics such at the \% Pollution Tolerant Valves (usually used in association with the Trophic Diatom Index, TDI) (Kelly and Whitton, 1995). See Table 1.

\section{Comparison of index values}

The comparison of the BDI and SADI index values for the 1960 and 2008 samples is provided in Table 4 . While the dataset is too small for statistical comparison, simple observation reveals that the values are essentially identical, despite the intervening period of 48 years. This, combined with the similarity in species assemblage, indicates that the contemporary stream conditions and those assessed 48 years previously are virtually unchanged.

\section{CONCLUSION}

The results clearly demonstrate the value of historically-curated diatom samples for the purposes of determining historical conditions. Similarly, these can be compared with contemporary values to inform the level of ecosystem change and, where relevant, utilise ecological information gleaned from the diatom assemblage to infer the possible cause thereof. As with other work, such as that for the Jukskei River catchment (Gauteng Province, South Africa), this assessment illustrates the value of the historical diatom data, as well as the use of diatoms for determining the ecological status of rivers and streams (Taylor et al., 2005).

\section{ACKNOWLEDGEMENTS}

The City of Cape Town is thanked for granting permission to collect samples. J.C. Taylor is the recipient of South African National Research Foundation (NRF) incentive funding.

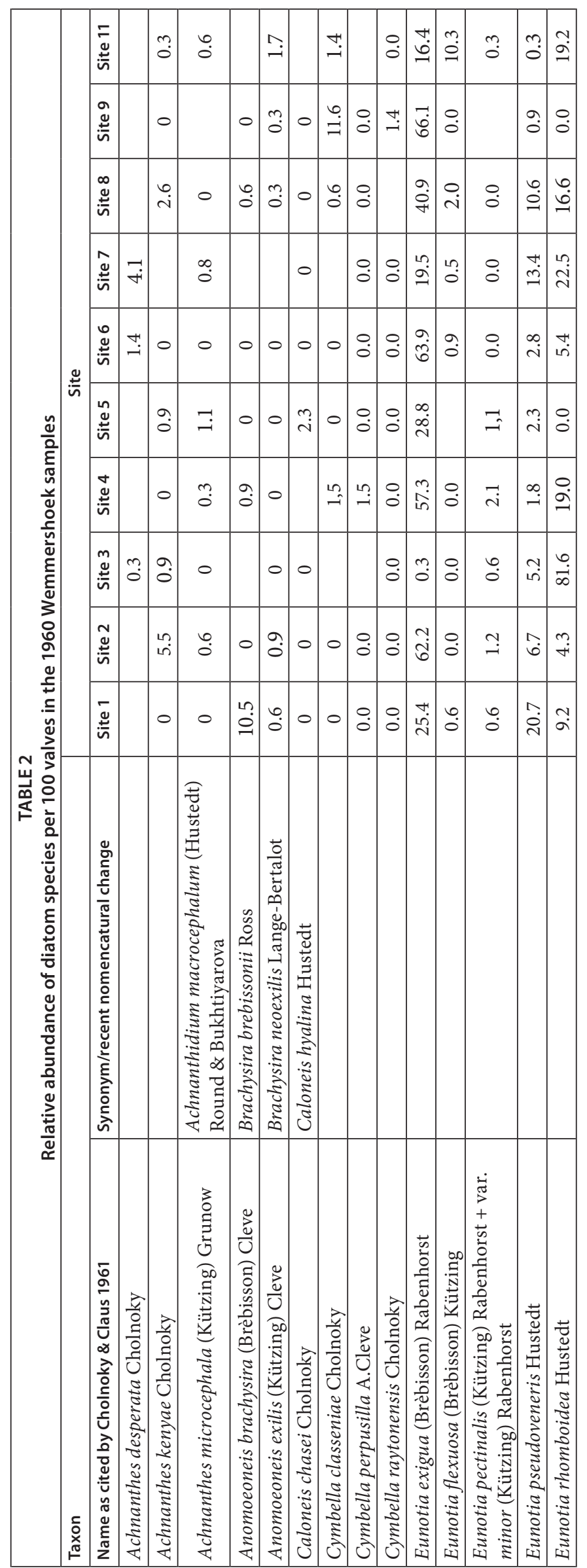




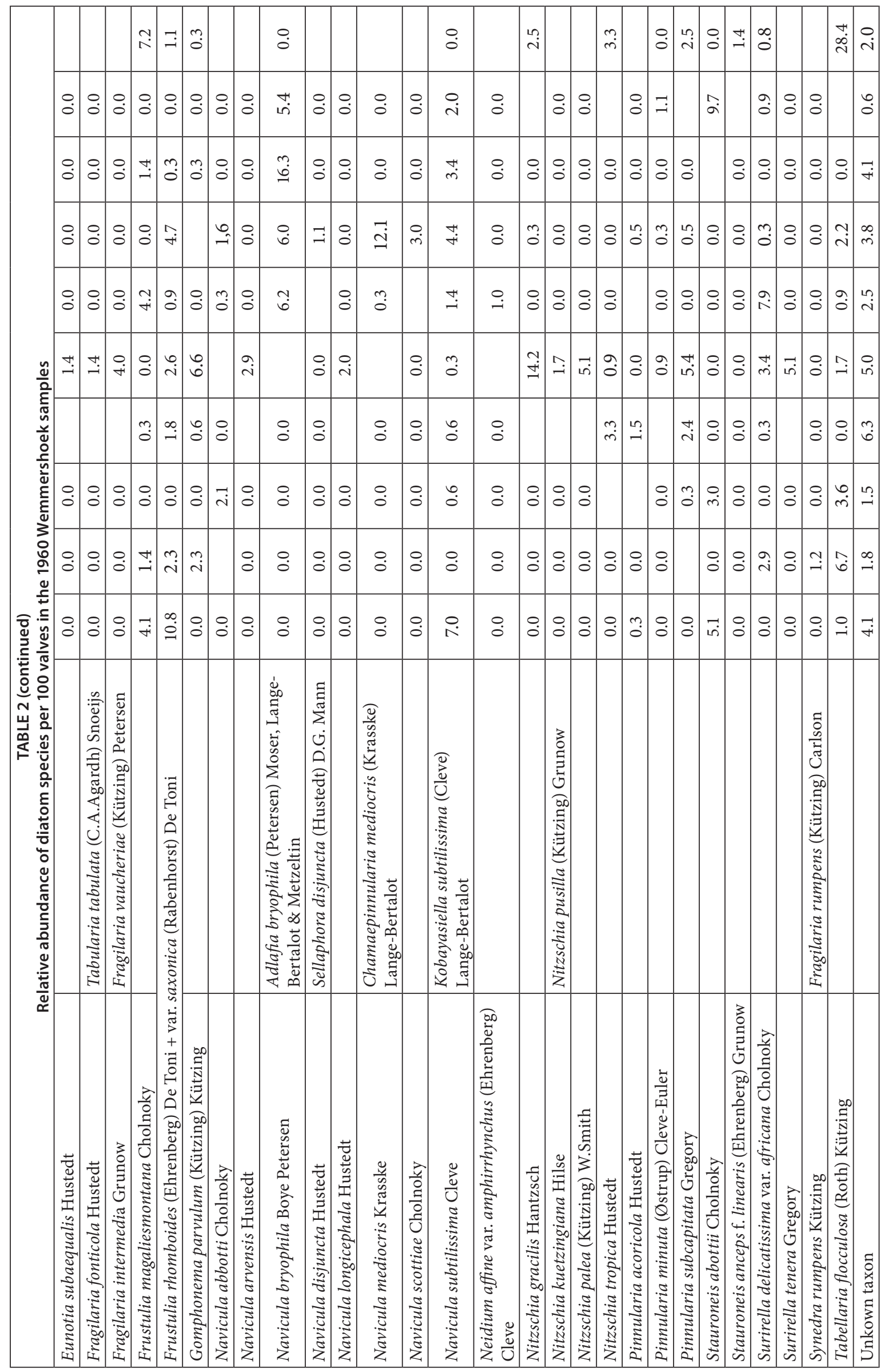




\begin{tabular}{|c|c|c|c|c|c|c|c|}
\hline $\begin{array}{r}\text { TABLE } \\
\text { Relative abundance of diatom species per } 100\end{array}$ & res in $t$ & 2008 & emmer & noek sa & ples & & \\
\hline 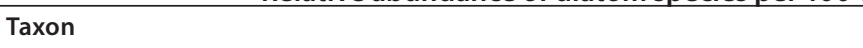 & & & & Site & & & \\
\hline & Site 2 & Site 3 & Site 4 & Site 7 & Site 8 & Site 10 & Site 11 \\
\hline Achnanthidium macrocephalum (Hustedt) Round \& Bukhtiyarova & 0.0 & 0.0 & 0.0 & 0.0 & 0.0 & & 0.5 \\
\hline Achnanthidium minutissimum (Kützing) Czarnecki & 0.0 & & 8.8 & 0.0 & 0.0 & 0.0 & \\
\hline Achnanthidium sp. & 3.5 & 0.8 & 0.0 & 0.3 & 0.3 & 7.3 & 0.3 \\
\hline Amphora sp. & 0.3 & 0.3 & 0.0 & & 0.8 & 0.0 & \\
\hline Brachysira brebissonii Ross & 0.0 & 0.0 & 0.0 & & 0.8 & 0.0 & 4.0 \\
\hline Brachysira neoexilis Lange-Bertalot & 0.0 & 0.3 & 0.0 & 0.0 & 0.0 & & 0.8 \\
\hline Chamaepinnularia mediocris (Krasske) Lange-Bertalot & 0.5 & 0.0 & 0.5 & 0.0 & 0.0 & 0.0 & \\
\hline Craticula submolesta (Hustedt) Lange-Bertalot & 0.0 & 0.0 & 0.0 & 0.0 & 0.0 & 0.0 & \\
\hline Cyclotella ocellata Pantocsek & 0.0 & 0.0 & 0.0 & & 0.3 & 0.0 & \\
\hline Cymbella raytonensis Cholnoky & 0.0 & 0.0 & 0.0 & 0.0 & & 1.0 & 0.0 \\
\hline Diploneis smithii (Brébisson) Cleve & 0.0 & & 0.3 & 0.0 & 0.0 & 0.0 & \\
\hline Encyonema krasskei (Krammer) Krammer & 0.0 & 0.0 & 0.0 & 0.0 & 0.0 & & 0.3 \\
\hline Eunotia bilunaris (Ehrenberg) Mills & 0.0 & 2.5 & 0.0 & & 0.8 & 1.0 & 0.8 \\
\hline Eunotia exigua (Brébisson) Rabenhorst & 44.8 & 40.0 & 3.3 & 3.3 & 12.3 & 2.3 & 58.3 \\
\hline Eunotia flexuosa (Brébisson) Kützing & 0.3 & 0.3 & 0.0 & 0.3 & 4.5 & 0.0 & 18.3 \\
\hline Eunotia implicata Nörpel, Lange-Bertalot \& Alles & 0.0 & 1.3 & 0.0 & 0.0 & 0.0 & 0.0 & \\
\hline Eunotia incisa Gregory & 2.8 & 19.5 & 0.0 & 13.5 & 31.8 & 0.0 & \\
\hline Eunotia minor (Kützing) Grunow & 0.0 & 0.3 & 0.0 & 0.0 & 0.0 & 0.0 & \\
\hline Eunotia naegeli Migula & 0.0 & 0.0 & 0.0 & & 0.3 & 0.0 & 0.3 \\
\hline Eunotia pectinalis (Dyllwyn) Rabenhorst & 0.0 & 4.0 & 0.0 & 0.0 & 0.0 & & 1.0 \\
\hline Eunotia pectinalis var. undulata (Ralfs) Rabenhorst & 0.0 & 0.0 & 0.0 & 0.0 & 0.0 & 0.0 & \\
\hline Eunotia rhomboidea Hustedt & 4.3 & 14.0 & 0.0 & 6.5 & 18.3 & 1.3 & 10.8 \\
\hline Eunotia sp. 1 & 24.5 & 9.3 & 8.3 & 61.3 & 25.8 & 0.0 & 0.5 \\
\hline Eunotia sp. 2 & 0.0 & 0.0 & 0.0 & 0.0 & & 24.8 & 0.0 \\
\hline Eunotia sp. 3 & 0.0 & 0.0 & 0.0 & 0.0 & & 1.3 & 0.0 \\
\hline Eunotia sp. 4 & 0.0 & 0.0 & 0.0 & 0.0 & 0.0 & 0.0 & \\
\hline Eunotia sp. 5 & 0.0 & 0.0 & 0.0 & 0.0 & & 0.3 & 0.0 \\
\hline Eunotia sp. 6 & 0.0 & 0.0 & & 0.3 & 0.0 & 0.0 & \\
\hline Eunotia tenella (Grunow) Hustedt & 0.0 & 0.0 & 0.0 & 0.0 & & 23.3 & 0.0 \\
\hline Fragilaria gracilis Østrup & 0.5 & 0.0 & 0.0 & 0.0 & 0.0 & 0.0 & \\
\hline Fragilaria rumpens (Kützing) Carlson & 0.0 & 0.3 & 0.5 & 0.0 & 0.0 & 0.0 & \\
\hline Frustulia cf. magaliesmontana Cholnoky & 5.3 & 2.0 & 0.0 & & 2.8 & 0.0 & \\
\hline Frustulia crassinervia (Brébisson) Lange-Bertalot \& Krammer & 0.0 & 0.5 & 0.3 & 0.0 & & 0.5 & 0.0 \\
\hline Frustulia magna Metzeltin \& Lange-Bertalot & 0.0 & 0.0 & 0.0 & 0.0 & 0.0 & & 0.3 \\
\hline Frustulia sp. & 0.0 & 0.3 & 0.3 & 0.0 & & 1.0 & 0.0 \\
\hline Gomphonema auritum A.Braun ex Kützing & 0.0 & 0.0 & 0.0 & 0.0 & 0.0 & 0.0 & \\
\hline Gomphonema parvulum (Kützing) Kützing & 0.0 & & 0.8 & 0.0 & 0.0 & 0.0 & \\
\hline Gomphonema parvulum var. exilissimum Grunow & 0.0 & 0.0 & 0.0 & 0.0 & 0.0 & 0.0 & \\
\hline Gomphonema sp. & 0.0 & & 1.8 & 0.0 & 0.5 & 0.0 & \\
\hline Kobayasiella sp. & 0.0 & 0.0 & & 2.0 & 1.0 & 0.0 & \\
\hline Kobayasiella subtilissima (Cleve) Lange-Bertalot & 0.3 & 0.0 & 0.0 & 0.0 & & 2.0 & 0.3 \\
\hline Luticola mutica (Kützing) D.G. Mann & 0.0 & & 0.3 & 0.0 & 0.0 & 0.0 & \\
\hline Mayamaea fossalis (Krasske) Lange-Bertalot & 0.0 & 0.0 & & 0.3 & 0.0 & 0.0 & \\
\hline Meridion circulare (Greville) C.A.Agardh & 0.0 & 0.3 & 0.0 & 0.0 & 0.0 & 0.0 & \\
\hline Microcostatus sp. & 0.0 & 0.0 & & 0.3 & 0.0 & 0.3 & 0.0 \\
\hline Navicula angusta Grunow & 0.5 & 0.0 & 0.0 & 0.0 & 0.0 & 0.0 & \\
\hline Navicula lepidula Grunow & 0.0 & 0.0 & 0.0 & 0.0 & 0.0 & & 0.3 \\
\hline Navicula notha Wallace & 0.0 & 0.0 & 0.0 & 0.0 & 0.0 & & 0.3 \\
\hline Navicula sp. & 0.8 & 0.0 & 0.0 & 0.0 & 0.0 & 0.0 & \\
\hline Navicula tenelloides Hustedt & 0.0 & 0.0 & 0.0 & 0.0 & 0.0 & 0.0 & \\
\hline Navicula veneta Kützing & 0.0 & 0.0 & 0.0 & 0.0 & & 0.3 & 0.0 \\
\hline Nitzschia acidoclinata Lange-Bertalot & 0.0 & 0.0 & 0.0 & 0.0 & & 0.3 & 0.0 \\
\hline
\end{tabular}




\begin{tabular}{|l|l|l|l|l|l|c|c|}
\hline \multicolumn{7}{|c|}{ TABLE 3 (continued) } \\
\multicolumn{7}{|c|}{ Relative abundance of diatom species per 100 valves in the 2008 Wemmershoek samples } \\
\hline Nitzschia hantzschiana Rabenhorst & 0.0 & & 0.3 & 0.0 & 0.0 & 0.0 & \\
\hline Nitzschia sp. & 0.0 & 0.5 & 0.0 & & 0.3 & 0.0 & \\
\hline Nupela sp. & 0.0 & 0.0 & & 11.8 & 0.0 & 0.0 & \\
\hline Pinnularia divergens W.M.Smith & 0.0 & 0.0 & 0.0 & 0.0 & 0.0 & 0.0 & \\
\hline Pinnularia sp. & 0.3 & 0.5 & 0.0 & 0.5 & 0.0 & 1.3 & 0.0 \\
\hline Placoneis sp. & 0.0 & 0.0 & 0.0 & 0.0 & & 0.3 & 0.0 \\
\hline Psammothidium abundans (Manguin) Bukht. \& Round & 0.0 & & 18.3 & 0.0 & 0.0 & 0.0 & \\
\hline Psammothidium chlidanos (Hohn \& Hellerman) Lange-Bertalot & 11.3 & 2.0 & 0.0 & 0.0 & 0.0 & 0.0 & \\
\hline Psammothidium oblongellum (Østrup) Van de Vijver & 0.3 & 0.0 & 55.8 & 0.0 & 0.0 & 0.0 & \\
\hline Sellaphora seminulum (Grunow) D.G. Mann & 0.0 & & 0.8 & 0.0 & 0.0 & 0.0 & \\
\hline Stauroneis kriegeri Patrick & 0.0 & & 0.3 & 0.0 & 0.0 & 0.0 & \\
\hline Stenopterobia delicatissima (Lewis) Brébisson & 0.0 & 1.3 & 0.0 & 0.0 & & 32.0 & 2.5 \\
\hline Tabellaria flocculosa (Roth) Kützing & 0.3 & 0.3 & 0.0 & 0.0 & 0.0 & & 1.0 \\
\hline
\end{tabular}

\begin{tabular}{|c|c|c|c|c|c|c|}
\hline \multicolumn{7}{|c|}{$\begin{array}{c}\text { TABLE } 4 \\
\text { Comparison of the BDI and SADI values for the } 1960 \text { and } 2008 \\
\text { Wemmershoek samples }\end{array}$} \\
\hline & \multicolumn{3}{|c|}{1960} & \multicolumn{3}{|c|}{2008} \\
\hline & \%PTV & BDI & SADI & \%PTV & BDI & SADI \\
\hline Site 1 & 0 & 20 & 19.5 & \multicolumn{3}{|c|}{ Not sampled } \\
\hline Site 2 & 2 & 20 & 19.6 & 0 & 20 & 19.4 \\
\hline Site 3 & 0 & 20 & 15.6 & 0 & 20 & 19 \\
\hline Site 4 & 4 & 20 & 18.7 & 1.8 & 18.9 & 17.7 \\
\hline Site 5 & 30.3 & 17.2 & 14.7 & \multicolumn{3}{|c|}{ Not sampled } \\
\hline Site 6 & 0 & 20 & 19.7 & \multicolumn{3}{|c|}{ Not sampled } \\
\hline Site 7 & 12.4 & 20 & 17.9 & 0 & 20 & 19 \\
\hline Site 8 & 0 & 20 & 19.1 & 0 & 20 & 18.5 \\
\hline Site 9 & 0 & 20 & 19.8 & 0.3 & 20 & 19.8 \\
\hline Site 11 & 6.1 & 20 & 18.4 & 0 & 20 & 19.5 \\
\hline
\end{tabular}

$P T V=$ Pollution Tolerant Valves; BDI = Biological Diatom Index;

$S A D I=$ South African Diatom Index. Max Index Value $=20$

Any opinions, findings and conclusions or recommendations expressed in this material are those of the author(s) and therefore the NRF does not accept any liability in regard thereto.

\section{REFERENCES}

ALLANSON BR, HART RC, O'KEEFFE JA and ROBARTS RD (1990) Inland Waters of Southern Africa: An Ecological Perspective. Monographiae Biologicae Vol 64. Kluwer Academic Publishers, Dordrecht

CHOLNOKY BJ and CLAUS G (1961) Beiträge zur kenntnis der Algenflora und der ökologie der diatomeen in dem stausee Wemmershoek-Dam nahe Kapstadt. Österr. Botan. Zeitschrift 108 325-350.

HARDING WR, ARCHIBALD CGM, TAYLOR JC and MUNDREE S (2004) The South African Diatom Collection: An Appraisal and Overview of Needs and Opportunities. WRC Report No. TT242/04. Water Research Commission, Pretoria. ISBN: 1-77005-274-7.

HARDING WR, ARCHIBALD CGM and TAYLOR JC (2005) The relevance of diatoms for water quality assessment in South Africa: A position paper. Water SA 31 41-46.

HARDING WR and TAYLOR JC (2011) The South African Diatom Index (SADI) - A Preliminary Index for Indicating Water

Quality in Rivers and Streams in Southern Africa. WRC Report No. 1707/1/11. Water Research Commission, Pretoria. ISBN: 978-1-4312-0172-3.

KELLY MG, CAZUBON A, CORING E, DELL'UOMO A, ECTOR L, GOLDSMITH B, GUASCH H, HÜRLIMANN J, JARLMAN A, KAWECKA B, KWANDRANS J, LAUGASTE R, LINDSTRøM E-A, LEITAO M, MARVAN P, PADISÁK J, PIPP E, PRYGIEL J, ROTT E, SABATER S, VAN DAM H and VINCENT J (1998) Recommendations for the routine sampling of diatoms for water quality assessments in Europe. J. Appl. Phycol. 10 215-224.

KELLY MG and WHITTON BA (1995) The trophic diatom index: a new index for monitoring eutrophication in rivers. J. Appl. Phycol. $7433-444$.

KELLY MG, GÓMEZ-RODRÍGUEZ C, KAHLERT M, ALMEIDA SFP, BENNETT C, BOTTIN M, DELMAS F, DESCY J-P, DÖRFLINGER G, KENNEDY B, MARVAN P, OPATRILOVA L, PARDO I, PFISTER P, ROSEBERY J, SCHNEIDER S AND VILBASTE $S$ (2012) Establishing expectations for pan-European diatom based ecological status assessments. Ecol. Indic. 20 177-186.

LECOINTE C, COSTE M and PRYGIEL J (1993) "Omnidia": Software for taxonomy, calculation of diatom indices and inventories management. Hydrobiologia 269/270 509-513.

RIVER HEALTH PROGRAMME (2005) State-of-rivers report: Monitoring and managing the ecological state of rivers in the Crocodile (West) Marico Water Management Area. Department of Environmental Affairs and Tourism, Pretoria.

TAYLOR JC, HARDING WR, ARCHIBALD CGM and VAN RENSBURG L (2005) Diatoms as indicators of water quality in the Jukskei-Crocodile river system in 1956 and 1957, a re-analysis of diatom count data generated by BJ Cholnoky. Water SA 31 237-246.

TAYLOR JC, JANSE VAN VUUREN MS and PIETERSE AJH (2007a) The application and testing of diatom-based indices in the Vaal and Wilge rivers, South Africa. Water SA 33 51-60.

TAYLOR JC, HARDING WR and ARCHIBALD CGM (2007b) A Methods Manual for the Collection, Preparation and Analysis of Diatom Samples. Version 1.0. WRC Report No. TT281/07. Water Research Commission, Pretoria. ISBN: 1-77005-483-9.

TAYLOR JC, BILLS R and HARDING WR (2011) The South African Diatom Collection: an update. Afr. J. Aquat. Sci. 36 113-114.

TELFORD RJ, JUGGINS S, KELLY M and LUDES B (2002) Diatom Applications. In: Du Buf H and Bayer M (eds) Automatic Diatom Identification. World Scientific Publishing, Singapore. ISBN: 981-02-4886-5.

YALLOP M, HIRST H, KELLY M, JUGGINS S, JAMIESON J and GUTHRIE R (2009) Validation of ecological status concepts in UK rivers using historical diatom samples. Aquat. Bot. 209 289-295. 